\section{Dihtievskiy 0., Kvasnikov V.}

\title{
ANALYSIS OF THE METHODS OF MEASUREMENT OF THE CYLINDRICAL GEAR INVOLUTE
}

Об'єктом дослідження в даній роботі є процес вимірювання евольвенти ииліндричного зубчастого колеса шляхом використання координатно-вимірювальних машин на нових фізичних принципах, обладнанні та методах. До теперішнвого часу метрологічне забезпечення вимірювання параметрів зубчастих коліс спиралося на гаму засобів зубовимірювальної техніки. Всі вони мають обмежений діапазон вимірювання параметрів, різну точність і номенклатуру вимірюваних значень. Багато з них морально застаріли, не автоматизовані, не мають виходу на комп'ютерні засоби та не забезпечують сучасного рівня точності, інформативності та швидкодіі. В силу иього, все більше застосовується в практиці метрологічне забезпечення зубчастих коліс та знаходять вимірювання геометричних параметрів їх евольвентних поверхонь на координатно-вимірювальних машинах. Істотною перевагою є той факт, що на координатно-вимірювальних машинах за одну установку може вимірюватися декілька геометричних параметрів поверхні зубчастого колеса. При цвому розроблене математичне забезпечення дозволяє оцінити похибки вимірювання $і$ дати їх графічне відображення. У роботі розглянуто еталонну базу в області евольвентометрії, що вимагає ї створення з урахуванням детального аналізу нових принципів вимірювання, необхідність обгрунтування ïx точності, розширення діапазону і номенклатури вимірюваних параметрів. А отже, виробництво нових модифікацій украйнських засобів вимірювання, заснованих на нових принципах контролю та контрольновимірювальних приладах провідних зарубіжних виробників в області евольвентометрії, є перспективним. Розглянуто також комплекс робіт зі створення системи забезпечення єдності вимірювання геометричних параметрів зубчастих коліс. Це вимагає перегляду, систематизації та розвитку методів і засобів метрологічного забезпечення. Запропоновано математичний опис кривої евольвенти зубчастого колеса методом триангуляціӥ багатозв'язних областей та опис геометричної моделі евольвенти за допомогою тренда. Надані рекомендації щодо застосування методу опису зубчастого ииліндричного колеса з евольвентним профілем. Запропонований метод дає змогу підвищити точність вимірювання на координатно-вимірювальних машинах.

Ключові слова: евольвентний профіль, зубчасте колесо, очінка похибки вимірювання, точність вимірювання, координатно-вимірювальна машина.

\section{Introduction}

The existing traditional devices for measuring the parameters of an involute profile are used as a standard of a real material object - the manufactured involute surface, which has, although small, but real form errors - a deviation from the theoretical involute. In the coordinate measuring machine, as the standard of an involute profile, its ideal representation is used in the form of a mathematical model with which the measured profile of the involute type is compared.

Traditional devices for measuring the parameters of an involute profile are created in the process of measuring movement in an involute with the help of mechanical elements of coordinate measuring machines. At the same time, there is an error in the process of movements when the main circle is run in at the moment of involute formation, and inaccuracies in the shape of the mechanical elements of the device is another source of error.

In the coordinate measuring machine, in contrast to traditional devices for measuring the parameters of the involute profile, it is not necessary to use special mechanical elements of the device, and, therefore, there are no similar error components.

All complex movements of coordinate measuring machines, necessary for the formation of an involute, are represented in digital form, which allows for the introduction of a trajectory. In this case, the tolerance discreteness of linear displacements reaches $0.1-0.2 \mu \mathrm{m}$, and the rotation tolerance discreteness resolution is $0.05 \mathrm{~mm}$.

The presence of modern computer software in coordinate measuring machines allows for automatic processing of measurement results. And also to increase the informativeness of the results due to the possibility of graphical information output and significantly improve the measurement accuracy due to the mathematical compensation of errors of systematic components. It is also possible to reduce random errors due to statistical processing.

All this creates prerequisites for the development and introduction of modern precision coordinate methods and means of measuring the geometric parameters of an involute profile, as well as their metrological support, on the basis of coordinate measuring machines.

Therefore, it is relevant to study the measurement of the cylindrical gear's involute by using coordinate measuring machines based on new physical principles, equipment and methods.

\section{The object of research and its technological audit}

The object of research is the process of measuring the involute of a cylindrical gear by using coordinate measuring 
machines based on new physical principles, equipment and methods.

Coordinate measuring machines are based on precise measuring transducers and computing equipment. They are characterized not only by high measurement performance, but also by a significant dynamic range [1]. At the same time, the effective use of coordinate measuring machines is associated with the solution of a number of metrological tasks, primarily, with ensuring their certification, testing, calibration and calibration.

At the present stage of development of technology, one of the key shortcomings, which design and technological bureaus work to eliminate, is the precision of production and control of the precision wheel.

\section{The aim and objectives of research}

The aim of research is development of a method for controlling an involute of a cylindrical gear using a coordinate measuring machine and a mathematical description using the triangulation method.

To achieve this aim it is necessary to perform the following objectives:

1. To analyze the gear geometry with involute profile.

2. To perform a mathematical description of the gear involute curve by the method of triangulation of multiply connected domains.

\section{Research of existing solutions of the problem}

Today, at the disposal of the industry a huge number of complex and expensive dental toilets [2, 3], which are equipped with almost all enterprises producing and controlling gears. Today in Ukraine at industrial enterprises there are more than ten thousand tools used to measure equipment of the whole range of geometric parameters [4, 5]. The widespread use of gears in many branches of engineering and instrument-making poses the task of developing metrological support for their production. This is due to the requirements of improving the accuracy, quality and competitiveness of products where they are used.

Among the main directions of solving the problem of measuring cylindrical gears with involute profile can be identified $[6,7]$. But in these studies, control of the gear of the tooth by using coordinate measuring machines based on new physical principles, equipment and methods is not considered.

The authors of $[8,9]$ show algorithms and programs for the triangulation of a two-dimensional region of arbitrary shape, however, there is an unresolved question of the mathematical description of a gear involute curve by the method of triangulation of multiply-connected domains.

An alternative solution to the problem of a mathematical model and an algorithm for analyzing the contact stresses of gears is described in [10,11]. However, these papers do not provide for triangulation of multiply connected domains.

The profile modification of the gears of cylindrical gear involute with regard to the deformation of the gearing is considered in [12, 13], which emphasizes the inaccuracy of the method for describing the geometric parameters of an involute gear. In papers [14, 15], the importance of automating the monitoring of parameters of gears is emphasized. But automation of the process leads to an increase in measurement error.

Thus, the results of literary analysis suggest that the development of a method for measuring involute cylindrical gears is reasonable and promising.

\section{Methods of research}

During the study were used:

- theory of the geometric construction of an involute of a circle;

- theory of linear equations of the gearing involute; - method of triangulation of multiply connected domains;

- experimental laboratory tests to obtain statistical data, processing and analysis of the results.

\section{Research results}

To measure the main profile of the teeth of cylindrical gears used in mechanical engineering, the construction of an involute profile is primarily carried out. A flat involute of a circle is called the trajectory of any point, for example, A (Fig. 1), a straight line that rolls without sliding along a circle of radius $r_{b}$; such a circle is called evolute, or the main circle, and a straight line is a generating line.

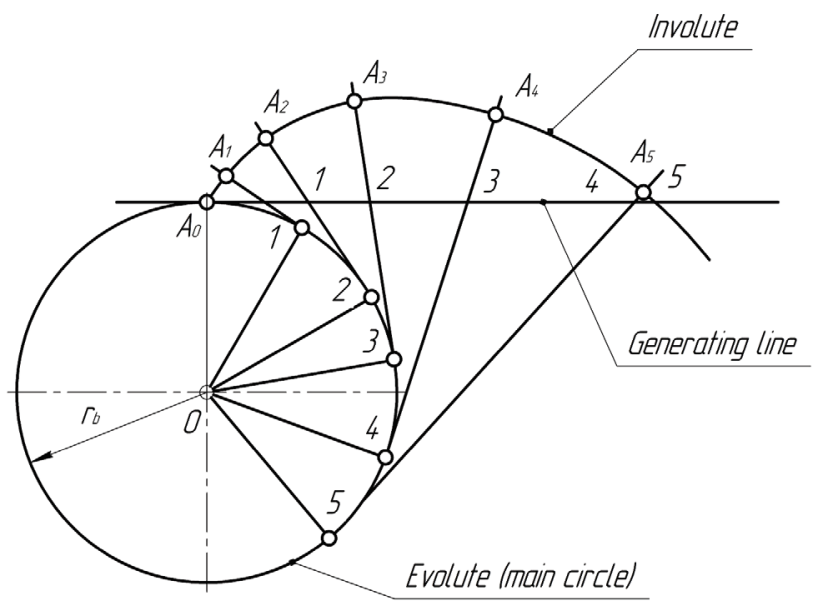

Fig. 1. Construction of an involute of a circle

The construction of the involute of the circle is shown in Fig. 1. Let's draw a generating line to the main circle, touching the point $A_{0}$. Then let's roll the generating line along the main circle without sliding. To do this, let's lay off a point $A_{0}$ on a generating line a series of identical segments $A_{0}-1,1-2,2-3$, and so on. On the main circle, let's single out arcs from this point equal to these segments.

When rolling a straight line in a circle without sliding, the point 1 coincides with a point $1^{\prime}$, point 2 - with a point 2', etc. Let's draw through points $1^{\prime}, 2^{\prime}, 3^{\prime}$ etc. the tangents to the circle and set off the segments equal to the straight line segments on the point of contact. Connecting the points $A_{0}, A_{1}, A_{2}$ and so on a smooth curve, let's obtain an involute.

Equations of the involute gears are obtained from the condition of rolling or forming a generating line along the main circle without sliding. To do this, let's consider some arbitrary position of the generating line, which is shown 
in Fig. 2 and which corresponds to an involute point $Y$. Let the coordinates of the involute point $Y$ of the gear be: $r_{y}$ - radius vector and $\theta$ - angle of deviation of the radius vector $r_{y}$ from the radius $r_{A}$ drawn through the beginning of the involute $A$.

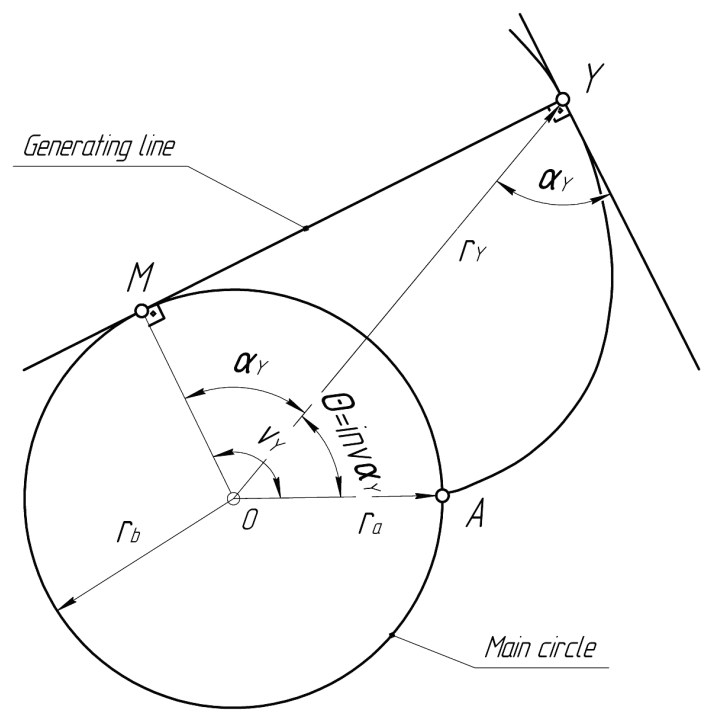

Fig. 2. Positions of the generating line

Let's draw a tangent through the point $Y$ to the main circle of radius $r_{B}$. The point of contact $M$ for the involute at a point $Y$ is the center of curvature, and the segment $M Y$ is its instantaneous radius of curvature. Let's connect a point of contact $M$ with the center of the main circle $O$ and designate the angle between the half lines $O M$ and $O Y$ as $\alpha_{y}$. This angle is called the angle of the profile - the sharp angle between the tangent to the profile at the corresponding point $Y$ and the radius-vector of this point $r_{y}$. Obviously, this angle is equal to the angle $M O Y$, since the line $O M$ and the tangent at the point $Y$ are parallel to each other. From the triangle $O M Y$ let's have:

$$
r_{y}=\frac{r_{b}}{\cos \alpha_{y}} .
$$

Since the involute obtained by rolling a generating line relative to the main circle without sliding, then $M Y=M A$. Considering that $M Y=r_{b} \operatorname{tg} \alpha_{y}$ and $M A=r_{b}\left(\alpha_{y}+\theta\right)$ let's obtain:

$$
r_{b} \operatorname{tg} \alpha_{y}=r_{b}\left(\alpha_{y}+\theta\right)
$$

or

$$
\operatorname{tg} \alpha_{y}=\alpha_{y}+\theta \text {. }
$$

Solving this equation for $\theta$, let's have:

$$
\theta=\operatorname{tg} \alpha_{y}-\alpha_{y} .
$$

Let's denote $\operatorname{tg} \alpha_{y}-\alpha_{y}$ by inv $\alpha_{y}$ and calculate as follows:

$$
\operatorname{inv} \alpha_{y}=\operatorname{tg} \alpha_{y}-\alpha_{y} .
$$

The angle $i n v \alpha_{y}=\theta$ is called the involute angle; it denotes the angle between the radii drawn through the beginning of the involute $A$ and the point $Y$. For a involute function, tables are compiled from which the angle $\alpha_{y}$ can determine the function inv $\alpha_{y}$ or vice versa.

Equations (4) and (5) are the equations of the involute of a circle in parametric form.

The radius of involute curvature at a point $Y$ :

$$
\rho_{y}=M Y=r_{b} \operatorname{tg} \alpha_{y}=r_{b} v_{y} .
$$

Let's note that the position of a point $Y$ on an involute can be specified by any angle of angles $\alpha_{y}, v_{y}=\alpha_{y}+i n v \alpha_{y}$, $\alpha_{y}$, or by a radius vector $r_{y}$ passing through the beginning of the involute $A$ and by a radius $\rho_{y}=M Y$ drawn through the center of curvature $M$ of the involute at a point $Y$.

The task of the synthesis of an involute gear is determination of its geometrical parameters, as well as the qualitative characteristics (coefficient of overlap, relative slip).

To start, select the source data (number of teeth $z$, module $m$ ), parameters of the initial contour (tooth head height ratio $h_{a}$, radial clearance coefficient $c^{*}$, profile angle $\alpha$ ). And then calculate the dimensions of the ele-

\begin{tabular}{|c|c|c|c|}
\hline \multicolumn{2}{|c|}{ What it is necessary to find } & \multirow{2}{*}{$\begin{array}{l}\text { Measuring } \\
\text { device }\end{array}$} & \multirow{2}{*}{ Formula } \\
\hline Name & Designation & & \\
\hline Gearing pitch & $p$ & $\begin{array}{l}\text { Pitch gauge } \\
\text { (Ukraine) }\end{array}$ & $p=\pi m$ \\
\hline Pitch circle radius & $\Gamma_{1}$ & $\begin{array}{l}\text { Involutemeter } \\
\text { (Germany) }\end{array}$ & $I_{1}=\frac{m z}{2}$ \\
\hline Main circle radius & $\Gamma_{b 1}$ & $\begin{array}{l}\text { Involutemeter } \\
\text { (Germany) }\end{array}$ & $\Gamma_{b 1}=r_{1} \cos \alpha$ \\
\hline Vertex circle radius & $\Gamma_{a 1}$ & $\begin{array}{l}\text { Involutemeter } \\
\text { (Germany) }\end{array}$ & $\Gamma_{a 1}=m\left(\frac{z}{2}+h_{a}\right)$ \\
\hline Cavity radius & $\Gamma_{f 1}$ & $\begin{array}{l}\text { Involutemeter } \\
\text { (Germany) }\end{array}$ & $\Gamma_{f 1}=m\left(\frac{z}{2}-h_{a}-c^{*}\right.$ \\
\hline Starting circle radius & $\Gamma_{w 1}$ & $\begin{array}{l}\text { Involutemeter } \\
\text { (Germany) }\end{array}$ & $\Gamma_{w 1}=\Gamma_{1}$ \\
\hline Tooth height & $h$ & $\begin{array}{c}\text { ШЦ-1 } \\
\text { (Ukraine) }\end{array}$ & $h=m\left(2 h_{a}+c^{*}\right)$ \\
\hline $\begin{array}{l}\text { Thickness of the tooth } \\
\text { on the pitch circle }\end{array}$ & $S_{1}$ & $\begin{array}{l}\text { Gear tooth } \\
\text { caliper gage } \\
\text { (Ukraine) }\end{array}$ & $S_{1}=m\left(\frac{\pi}{2} \operatorname{tg} \alpha\right)$ \\
\hline
\end{tabular}
ments of the gear according to the Table 1 and determine the means of measurement.

Table 1

Formulas for the theoretical calculation of the dimensions of the gear elements

After measuring all the geometrical parameters and determining the necessary coefficients, we can build up the tooth profiles (Fig. 3).

To begin, let's set aside the center distance $O_{1} O_{2}$ with the radii $r_{w 1}, r_{w 2}$ of the initial circles, build a circle, touch at a point $P$ (gear pole). Let's build the main circles with radii $r_{b 1}, r_{b 2}$ and draw a tangent to them $n n$. From the wheel centers, let's drop the perpendiculars to the tangent and get the points $N_{1}, N_{2}$ - the beginning and end of the theoretical line of engagement. Let's determine the arcs of the pitch circles, circles of hollows and peaks. Let's build the involute teeth of the gears on the measured points (Fig. 3).

It should be remembered that the radius of the circle of the hollows may be greater, equal or less than the radius of the main circle. It depends on the number of teeth of the gear and the offset factor. 


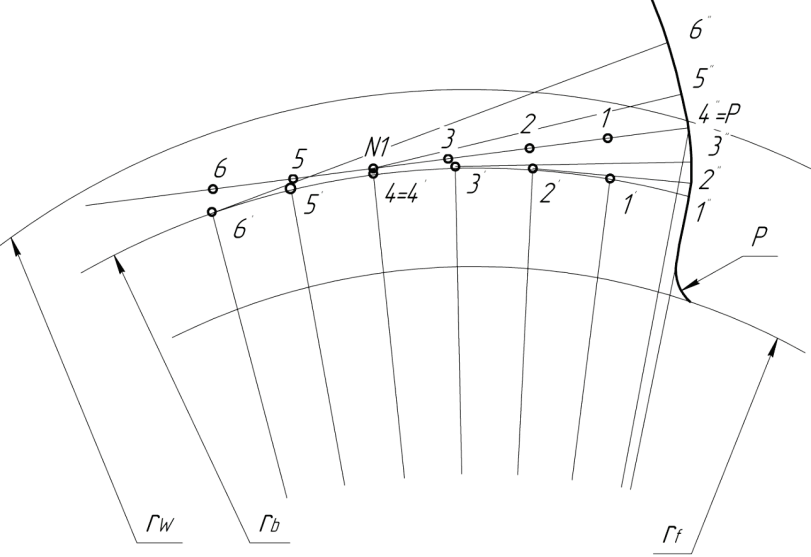

Fig. 3. Involute construction

Let's construct a full profile of a tooth. To do this, from the obtained involute curve along the pitch circle, let's single out the thickness of the tooth, which let's split in half. Let's connect this middle with the center of the gear and draw the axis of symmetry, relative to which let's build the second profile tooth curve (Fig. 4).

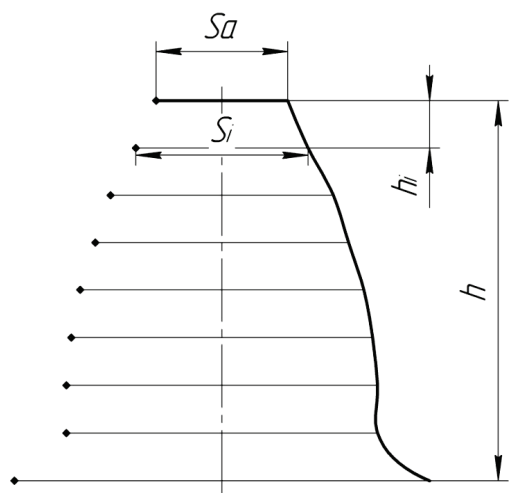

Fig. 4. Touth profile construction

Let's describe the involute curve by the triangulation method. In the process of splitting the boundary of the region and its triangulation, the function of steps is used, adjusting the dimensions of one-dimensional and triangular finite elements depending on their position in the region. The function of steps can be any positive function. In [1] one of its options is proposed:

$$
h(x, y)=h_{0}+\sum_{i=1}^{n} \frac{h_{i}-h_{0}}{1+\left(\frac{x_{i}}{A_{i}}\right)^{N_{i}}+\left(\frac{y_{i}}{B_{i}}\right)^{N_{i}}},
$$

where $h_{0}$ - the main grid spacing; $n$ - amount of concentration or rarefaction of the grid; $h_{i}-$ grid spacing at the center of the $i$-th concentration; $A_{i}, B_{i}$ - dimensions of the condensation region; $N_{i}$ - exponent characterizing the concentration gradient:

$$
\begin{aligned}
& \tilde{x}_{i}=\left(x-x_{i}\right) \cos \alpha_{i}+\left(y-y_{i}\right) \sin \alpha_{i}, \\
& \tilde{y}_{i}=\left(x-x_{i}\right) \sin \alpha_{i}+\left(y-y_{i}\right) \cos \alpha_{i},
\end{aligned}
$$

where $\left(x_{i}, y_{i}\right)$ - coordinates of the center of the $i$-th concentration; $\alpha_{i}-$ angle of rotation of the axes of the $i$-th concentration.
Let the limit of a multiply connected domain be formed by $N$ piecewise smooth closed contours defined in a Cartesian coordinate system $O_{x y}$ in a parametric form. Let's consider some piecewise-smooth contour $\Gamma$ (contour index is omitted) formed by $L$ smooth curves $\gamma_{n}, n=1, \ldots, L$, which parametric equations are:

$$
(x(t), y(t)) \equiv \vec{x}(t)=\vec{x}_{n}(t), t_{n}^{-} \leq t \leq t_{n}^{+},
$$

where $t_{n}^{-}, t_{n}^{+}$- limits of the parameter $t$ change for $\gamma_{n}$. From the condition of continuity and closure of the $\Gamma$ contour let's have:

$$
\vec{x}_{n}\left(t_{n}^{+}\right)=x_{n+1}\left(t_{n+1}^{-}\right) \text {, at } n=\overline{1, L-1}, \vec{x}_{1}\left(t_{1}^{-}\right)=\vec{x}_{L}\left(t_{1}^{-}\right) .
$$

Parameterization (1) must be such that for internal circuits the direction of the bypass with the growth of the parameter $t$ is clockwise, for the external contour counterclockwise.

$\Gamma$ splitting is carried out sequentially, starting with the first smooth curve $\gamma_{1}: \vec{x}=\vec{x}_{1}(t)$. The first node in $\Gamma$ is $\vec{y}_{1}=\vec{x}_{1}\left(t_{1}^{-}\right)$. Let's suppose that the first $l-1$ curves of the contour are already split $\Gamma$, the last node constructed on these curves are:

$$
y_{n_{l-1}}=x_{l-1}\left(t_{l-1}^{+}\right)=x_{l}\left(t_{l}^{-}\right)
$$

and split the curve $\gamma_{l}$ with the last node:

$$
y_{n_{l-1}+k}=x_{l}\left(t_{k}^{l}\right),
$$

where $t_{k}^{l}$ - the value of the $t$ for the last node $t_{k}^{l} \in\left(t_{l}^{-}, t_{l}^{+}\right)$

Let's denote by $s_{l}\left(t_{k}^{l}, t\right)$ the length of the part of the curve $\gamma_{l}$ corresponding to the value $t_{k}^{l}, t$ :

$$
s_{l}\left(t_{k}^{l}, t\right)=\int_{t_{k}^{l}}^{t}|\dot{\vec{x}}(t)| \mathrm{d} t, t \in\left[t_{k}^{l}, t_{l}^{+}\right],
$$

where $\dot{\vec{x}}(t)$ - the derivative of $t$ with respect to $\vec{x}(t)$.

When constructing a new node $\vec{y}_{n_{l-1}+k+1}$, the value of the function of steps $h(x, y)$ in the previous constructed $\vec{y}_{n_{l-1}+k}$ is calculated and let's find the solutions $t_{k+1}^{l}$ of the equation:

$$
s_{l}\left(t_{k}^{l}, t\right)=h\left(\vec{y}_{n_{l-1}+k+1}\right), t \in\left[t_{k}^{l}, t_{l}^{+}\right] .
$$

In the case of the existence of this equation $\left|\dot{\vec{x}}_{l}(t)\right|>0$. According to calculated value $t_{k+1}^{l}$ let's calculate $\vec{x}_{l}\left(t_{k+1}^{l}\right)$ and find the solution $t_{k+1}^{l}$ of the equation:

$$
s_{l}\left(t_{k}^{l}, t\right)=\frac{1}{2}\left[h\left(\vec{y}_{n_{l-1}+k}\right)+h\left(\vec{x}_{l}\left(t_{k+1}^{l}\right)\right)\right] .
$$

Let's consider the inequality:

$$
\left|\frac{d-s_{l}\left(t_{k}^{l}, t_{k+1}^{l}\right)}{s_{l}\left(t_{k}^{l}, t_{k+1}^{l}\right)}\right| \leq \varepsilon, d=\left|\vec{y}_{n_{l-1}+k}-s_{l}\left(t_{k+1}^{l}\right)\right| .
$$

The left side of inequality (4) is the relative difference between the length of the involute arc and the length $d$ of the segment corresponding to it, and which characterizes the deviation of the arc from the straight segment.

If inequality (4) is satisfied, then the point $\vec{x}_{l}\left(t_{k+1}^{l}\right)$ is declared a new node and proceeds to the construction 
of the next node. If inequality (4) is not fulfilled, the right-hand side of equation (3) is consistently reduced by a certain amount (for example, one-tenth of the righthand side) until (4) is satisfied. This situation arises when the length $d$ of a one-dimensional element, calculated according to the function of steps, is sufficiently «large» for an acceptable approximation by this element of the corresponding arc, and therefore, this length is gradually reduced to the necessary inequality (4). Then go to the construction of the next node $\vec{y}_{n_{l-1}+k+2}$.

The end of the procedure for constructing new nodes on the $l$-th contour $\Gamma$ curve is associated with the absence of a solution to equation (2) and is described in [2]

After we have split the limits of the domain of the involute, let's turn to the direct triangulation of each of its parts.

1. Let's find the section $z_{\min }$ of the current grid boundary (CGB), which has a minimum length $l_{\min }$ and nodes $x_{\min }^{1}, x_{\min }^{2}$. Let's denote $z_{\min }^{-}, z_{\min }^{+}$, respectively, preliminary and subsequent sections with respect to $z_{\min }$. Let's choose the section $z_{\text {min }}^{*}$ from $z_{\text {min }}^{-}, z_{\text {min }}^{+}$, the section that forms $z_{\min }$ with the smallest angle $\beta_{\text {min }}$. Let's denote the nodes of the selected pair of sections (this is either $z_{\min }^{-}, z_{\min }$, or $z_{\text {min }}, z_{\text {min }}^{+}$) as $x_{1}^{\min }, x_{2}^{\min }, x_{3}^{\min }$. If $\beta_{\min } \leq 80^{\circ}$ (otherwise go to procedure 4), then:

2. Let's carry out a check for hitting CGB nodes in a triangle $\Delta\left(z_{\min }, z_{\min }^{*}\right)$. If there are no such nodes, then go to procedure 3 , otherwise, from all the nodes that hit in the $\Delta\left(z_{\min }, z_{\text {min }}^{*}\right)$ nodes, select the node $\vec{y}_{*}$ closest to $z_{\min }$, and go to procedure 12 .

3. Let's consider a circle with a radius $1 / 2\left|x_{3}^{\min }-x_{1}^{\min }\right|$ and its center $\vec{x}_{c}, \vec{x}_{c}=\left(x_{1}^{\min }+x_{3}^{\min }\right) / 2$. If the CGB nodes do not fall into external half of a circle with respect to a triangle $\Delta\left(z_{\min }, z_{\min }^{*}\right)$, then proceed to procedure 13 . Otherwise, from all the nodes that fall, let's choose the node $\vec{x}_{m}$ closest to the segment $\left|x_{1}^{\min }, x_{3}^{\min }\right|$ and split the quadrilateral $\left(z_{\min }, z_{\min }^{*}, \vec{x}_{m}\right)$ into two triangles in such manner that the minimum angle that comes out of the triangles was maximum. Let's declare both obtained triangles as elements, remove the third $\left(z_{\min }, z_{\min }^{*}\right)$ from the CGB (determine the connectedness of the region, add two new sections $\left[x_{1}^{m i n}, \vec{x}_{m}\right]$, and proceed to procedure 1 .

4. Let's construct a point:

$$
\vec{x}_{*}=x_{\min }^{c}+h \vec{n}, x_{\min }^{c}=\frac{1}{2}\left(x_{\min }^{1}+x_{\min }^{2}\right),
$$

where $\vec{n}$ - normal to $z_{\min }$, directed inside the area:

$$
\begin{aligned}
& \left(x_{\text {min }}^{1}-x_{\text {min }}^{2}\right) \cdot \vec{n}=l_{\text {min }} \vec{e}_{3}, \vec{e}_{3}=(0.01), \\
& h_{c p}=\frac{1}{3} \sum_{i=1}^{3} h\left(\vec{\tau}_{i}\right), \vec{\tau}_{i}=x_{\text {min }}^{j}, j=1,2 ; \vec{\tau}_{3}=x_{\text {min }}^{c}+\frac{\sqrt{3}}{2} l_{\text {min }} \vec{n} .
\end{aligned}
$$

On the base of the section $z_{\text {min }}$, let's construct a rectangle $\vartheta$, one of the sides of which is $z_{\text {min }}$, and the other is directed along the normal and its length is equal to $2 h$, where $h$ is the height in $\Delta\left(z_{\min }, \vec{x}_{*}\right)$, dropped to $z_{\min }$. With the help of the control domain $\vartheta$, let's establish the criteria for the proximity of the constructed new node $\vec{x}_{*}$ to the previously constructed nodes and sections. If $\vec{x}_{*}$ in a certain sense it is close to nodes or sections, then we refuse to build a new node, and from the close nodes to build a new element, let's choose the best one.
Let's define two sets $M_{0}$ and $M_{1}$ :

$$
M_{0}=\left\{n: \vec{x}_{n} \in \vartheta, \vec{x}_{n} \neq x_{\min }^{i}, i=1,2\right\},
$$

where $M_{0}$ - set of numbers of CGB nodes, which fell $\vartheta$ except for the numbers of nodes $x_{\min }^{1}, x_{\min }^{2}$.

$$
M_{1}=\left\{n: z_{n} \cap \delta \vartheta \neq 0, z_{n} \neq z_{\min }\right\},
$$

where $M_{1}$ - set of numbers of CGB sections that intersect $\delta \vartheta$, with the exception of the minimum section number $z_{\text {min }}$.

Let's introduce two additional points $\vec{z}_{1}, \vec{z}_{2}$ :

$$
\begin{aligned}
& \vec{z}_{i}=x_{\text {min }}^{i}+(-1)^{i} \Delta l \vec{r}, i=1,2, \\
& \vec{r}=\frac{1}{l_{\text {min }}}\left(x_{\text {min }}^{2}-x_{\text {min }}^{1}\right), \Delta l=\frac{1}{4}\left(h\left(x_{\text {min }}^{c}\right)-l_{\text {min }}\right) .
\end{aligned}
$$

Let's determine the angle $\tau$ in the triangle $\Delta\left(\vec{x}_{*}, \vec{z}_{1}, \vec{z}_{2}\right)$ based on $\left[\vec{z}_{1}, \vec{z}_{2}\right]$ and suppose $\vec{z}_{\tau}=\vec{z}_{1}$ if $z_{\text {min }}^{*}=z_{\text {min }}^{-}, \vec{z}_{\tau}=\vec{z}_{2}$ and if $z_{\text {min }}^{*}=z_{\text {min }}^{+}$(see item 1).

Let's determine the angle $\alpha_{1}$ at the vertex $\vec{x}_{*}$ of the triangle $\Delta\left(\vec{z}_{1}, \vec{z}_{2}, \vec{x}_{*}\right)$. If $\alpha_{1} \geq 30^{\circ}$ and $\beta_{\text {min }}-\tau \geq 20^{\circ}$, then the point $\vec{x}_{*}$ is declared a new node and go to procedure 14 . If $\alpha_{1}<30^{\circ}$, then the point $\vec{x}_{*}$ is redistributed so that the new angle $\alpha_{1}=30^{\circ}, \quad \vec{x}_{*}=x_{\text {min }}^{c}+\left(\vec{z}_{2}-x_{\text {min }}^{c}\right) \tan 75^{\circ} n$, while, if $\beta_{\text {min }}-75^{\circ}<20^{\circ}$, then go to procedure 2 .

5 . Let's introduce the whole switch parameter $I N D$ and suppose $I N D=0$. If $M_{0} \neq 0$ (otherwise, go to procedure 9), then from $M_{0}$ select the number $m$ at which the corresponding node $\vec{x}_{m}$ is closest to $z_{\min }$. To do this, determine the distance $l_{i}$ from the points $\vec{x}_{i}, i \in M_{0}$ to $z_{\min }$ and choose:

$$
l_{m}=\min _{i \in M_{0}} \rightarrow m \text {. }
$$

Let's consider the angle $\alpha$ at the vertex $\vec{x}_{m}$ in the triangle $\Delta\left(\vec{x}_{m}, \vec{z}_{1}, \vec{z}_{2}\right)\left(\vec{z}_{i}\right.$ are defined in 4 ). If $\alpha_{1} \geq 30^{\circ}$ (otherwise, let's proceed to procedure 8$)$, then let's carry out a check on the intersection of the segment $\left[\vec{x}_{m}, x_{\min }^{1}\right]$ with the CGG sections having the numbers from the $M_{1}$ numbers of the sections adjacent to the nodes $\vec{x}_{m}, x_{\text {min }}^{1}$. Let's denote for convenience $\vec{x}_{m}$ by $\vec{y}_{*}$.

6 . If there are no ordinary points, then go to either procedure $12($ at $I N D=0)$ or procedure 14 (at $I N D=1)$. Otherwise, proceed to procedure 7 .

7. With the use of intersected section nodes $z_{p}$, let's construct anti-clockwise oriented triangles $\Delta\left(z_{\min }, \vec{x}_{k}\right)$, where $\vec{x}_{k}$ - nodes of section $z_{p}, \quad k \in\left\{k_{1}, k_{2}\right\}$. When constructing triangles, it is necessary to monitor their existence. From these triangles (if both exist) let's choose $\Delta\left(z_{\min }, \vec{x}_{k_{i}}\right), k_{i} \in\left\{k_{1}, k_{2}\right\}$ which has a minimum angle more (let's denote the minimum angle in any triangle $\Delta(z, \vec{x})$ by $\alpha(z, \vec{x})$. Denoting the selected node $\vec{x}_{k_{i}}$ by $\vec{y}_{*}$, let's check for the intersection of both sides $\Delta\left(z_{\min }, \vec{y}_{*}\right)$ with all parts of the CGB except for the minimum and sections adjacent to minimum angle and to the node $\vec{y}_{*}$, and proceed to procedure 6 .

8. The nearest node $\vec{x}_{m}$ is very far from $z_{\text {min }}\left(\right.$ since $\alpha_{1}<30^{\circ}$ ), therefore let's shift $\vec{x}_{*}$ to $z_{\min }$ so that the distance from its new position (let's denote this point by $\vec{y}_{*}$ ) to $z_{\min }$ be $l_{m} / 2, \vec{y}_{*}=x_{\min }^{c}+1 / 2 l_{m} \vec{n} ; l_{m}$, which defined in (5). In the triangle $\Delta\left(\vec{z}_{1}, \vec{z}_{2}, \vec{y}_{*}\right)$ let's determine the angle $\tau$ at the vertex $\vec{z}_{\tau} ; \vec{z}_{\tau}$ is defined in 4 . If $\beta_{\min }-\tau<20^{\circ}$, then go to procedure 2 , otherwise let's check for the intersection of one of the sides $\Delta\left(z_{\min }, \vec{y}_{*}\right)$ with sections with numbers $M_{1}$ with and go to procedure 6 . 
9. If $\beta_{\text {min }}-\tau<20^{\circ}$, then go to procedure 2 , otherwise from all the sections that cross $\delta \vartheta$ let's choose $z_{m_{1}}$ and $z_{m_{2}}$ the closest ones to $z_{\text {min }}$. To do this, let's consider all the intersection points $y_{i}^{1}$ of the sections $z_{k_{i}}, k_{i} \in M_{1}$, with the side $\Gamma_{1}$ of the rectangle $\vartheta$, which passes $x_{i}^{1}$ through, and similar points $y_{i}^{2}$ for $\Gamma_{2}$. Then the numbers $m_{1}$ and $m_{2}$ are defined as the numbers with $M_{1}$, deliver a minimum of expression $\left|y_{i}^{j}-y_{\text {min }}^{j}\right|$, that is:

$$
\min _{i \in M_{0}}\left|y_{i}^{j}-y_{\min }^{j}\right| \Rightarrow m_{j}, \quad j=\overrightarrow{1, N_{p}} .
$$

If $\Gamma_{1}$ and $\Gamma_{2}$ cross the various «closest sections», then $N_{p}=2$. If one of the sides $\Gamma_{i}$ of a section does not intersect or $\Gamma_{1}$ and $\Gamma_{2}$ intersects with the same section, then $N_{p}=1$ and let's consider only the number $m_{1}$.

10. Let's construct oriented triangles $\Delta\left(z_{\text {min }}, x_{m_{i 1}}^{j}\right)$, where $x_{m_{i 1}}^{j}-$ section nodes. Let's choose from $\Delta\left(z_{\text {min }}, x_{m_{i 1}}^{j}\right)$ a triangle with a minimum angle that is larger $\alpha\left(z_{\min }, x_{m_{\mathrm{i}}}^{j_{1}}\right) \geq \alpha\left(z_{\min }, x_{m_{\mathrm{in}}}^{j}\right)$, and proceed to the next procedure.

11. If $\alpha\left(z_{\min }, x_{m_{\mathrm{in}}}^{j_{1}}\right) \leq \alpha\left(z_{m_{i}}, \vec{x}_{*}\right)$, then go to procedure 14; otherwise, let's check the sides of the intersection $\Delta\left(z_{m_{i}}, x_{m_{i}}^{j}\right)$ with all the CGB sections, with the exception of the sections adjacent to the node $x_{m_{1}}^{j}$ and to the section $z_{\text {min }}$. In addition, let's conduct a check for the entry of CGB sections into this triangle with the exception of the node $x_{m_{i}}^{j}$ and the nodes $x_{\min }^{1}$ and $x_{\min }^{2}$. If the intersections and the nodes inside the triangle are not, then let's denote the node $x_{m \text {. }}^{j}$ as $x_{m_{i+1}}^{j}$ and proceed to procedure 12. If the intersection is or the triangle contains at least one CGB node, then from the list of parameter values $j$, let's select a new value $j_{2}$, go to the beginning of procedure 11 by renaming $j_{2}$ to $j_{i}$.

12. Let's declare the triangle $\Delta\left(z_{\min }, \vec{y}_{*}\right)$ as an element, delete $z_{\min }$ from the CGB, determine the number of connectedness of the domain, add two new sections $\left[x_{\min }^{1}, \vec{y}_{*}\right]$, $\left[\vec{y}_{*}, x_{\min }^{2}\right]$, and proceed to procedure 1 .

13. The triangle $\Delta\left(z_{\min }, z_{\min }^{*}\right)$ is declared an element, delete $z_{\min }, z_{\min }^{*}$ from the CGB, add one section $\left[x_{1}^{\min }, x_{3}^{\min }\right]$ and proceed to procedure 1 .

14. Let's declare the triangle $\Delta\left(z_{\min }, \vec{x}_{*}\right)$ as an element, delete $z_{\min }$ from the CGB, add two new sections $\left[x_{\min }^{1}, \vec{x}_{*}\right]$, $\left[\vec{x}_{*}, x_{\min }^{2}\right]$, and proceed to procedure 1 .

\section{SWOT analysis of research results}

Strengths. The formulas for improving the accuracy characteristics of the stabilization system and increasing its speed are derived, which allows to raise the characteristics of the equipment to a new level, higher than foreign analogues.

Weaknesses. The weak side is that in order to improve performance it is necessary to carry out more accurate calculations and calculate a larger data array, leading to the use of a new element base of the coordinate measuring machine.

A negative internal factor is an increase in production costs.

Opportunities. The proposed method allows to improve the measurement accuracy on coordinate measuring machines.

Threats. The absence of precision equipment in the machine tool park. An enterprise that wants to master this method must purchase high-precision equipment for measuring involute gears.

\section{Conclusions}

1. The gear geometry with involute profile is analyzed. Thus, an involute is constructed to measure the main profile of the teeth of cylindrical gears. Namely, it is established that the equation of the gear involute is obtained from the condition of rolling or forming a straight line along the main circle without sliding.

2. A mathematical description of the gear involute curve is made by the method of triangulation of multiply connected domains. It is established that in the process of splitting the boundary of a region and its triangulation, the function of steps is used, correcting the dimensions of one-dimensional and triangular finite elements.

\section{References}

1. Loktev D. A. Sovremennye metody kontrolia kachestva cilindricheskih zubchatyh koles // Metalloobrabotka. Oborudovanie i instrument dlia professionalov. 2009. Issue 4. P. 6-11.

2. Taic B. A. Tochnost i kontrol zubchatyh koles. Moscow: Mashinostroenie, 1972. 369 p.

3. Surkov I. V. Development of methods and means of coordinate measurements for linear and angular parameters of cutting instruments // Measurement Techniques. 2011. Vol. 54, Issue 7 P. 758-763. doi: http://doi.org/10.1007/s11018-011-9800-2

4. Nai-shi C., Wen L. Calculation of conformal mapping function of the tooth profile on evolvent gear by computer // Applied Mathematics and Mechanics. 1988. Vol. 9, Issue 11. P. 1101-1108. doi: http://doi.org/10.1007/bf02454514

5. Umanskii S. E. Algoritm i programma trianguliacii dvumernoi oblasti proizvolnoi formy // Problemy prochnosti. 1978. Issue 6. P. $83-87$

6. Guliaev K. I., Riazanceva I. L. Profilnaia modifikaciia zubev koles evolventnoi cilindricheskoi peredachi s uchetom deformacii zacepleniia // Izvestiia VUZov. Priborostroenie. 1981. Issue 5. P. 20-25.

7. Mathematical model and algorithm for contact stress analysis of gears with multi-pair contact / Medvedev V. I., Volkov A. E., Volosova M. A., Zubelevich O. E. // Mechanism and Machine Theory. 2015. Vol. 86. P. 156-171. doi: http://doi.org/10.1016/ j.mechmachtheory.2014.12.005

8. Goldfarb V. I., Trubachov E. S., Kuznetsov A. S. Load Distribution in Statically Loaded Spiroid Gear: proceedings // Power transmissions 2006. Novi Sad: Serbia \& Montenegro, 2006. P. 369-376.

9. Sakalo V. I., Shkurin A. A. Universalnaia programma trianguliacii dvumernoi oblasti proizvolnoi formy so sgushcheniiami setki // Problemy prochnosti. 1985. Issue 1. P. 106-108.

10. VDI/VDE 2607 Computer-aided evaluation of profile and helix measurements on cylindrical gears withnvolute profile. Dusseldorf, 2000. 46 p.

11. Bowden R. O., Hall J. D. Simulation Optimization Research and Development: proceedings // Winter Simulation Conference (Proc. 1998). Washington, 1998. P. 1693-1698. doi: http:/ doi.org/10.1109/wsc.1998.746048

12. Brennan R. W., Rogers P. Stochastic Optimization Applied to a Manufacturing System Operation Problem: proceedings // Winter Simulation Conference (Proc. 1995). Washington, 1995. P. 857-864. doi: http://doi.org/10.1109/wsc.1995.478870

13. Evans G. W., Stockman B., Mollaghasemi M. Multicriteria Optimization of Simulation Models: Winter Simulation Conference (Proc. 1991). Phoenix, 1991. P. 894-900. doi: http:// doi.org/10.1109/wsc.1991.185702

14. Goch G. Gear Metrology // CIRP Annals. 2003. Vol. 52, Issue 2. P. 659-695. doi: http://doi.org/10.1016/s0007-8506(07)60209-1

15. Surkov I. V. Avtomatizaciia kontrolia parametrov zubchatyh koles i peredach // Stankoinstrument. 2016. Issue 1. P. 80-87.

Dihtievskiy Alexander, Department of Computerized Electrotechnical Systems and Technologies, National Aviation University, Kyiv, Ukraine, e-mail: sasha.home89@ukr.net, ORCID: http://orcid.org/ 0000-0002-1202-3627

Koasnikov Volodymyr, Doctor of Technical Sciences, Honored Metrologist of Ukraine, Head of Department of Computerized Electrotechnical Systems and Technologies, National Aviation University, Kyiv, Ukraine, e-mail: kvp@nau.edu.ua, ORCID: http://orcid.org/ 0000-0002-7799-0001 